\section{$\xi_{\text {ma }}$ (a)}

\section{OPEN ACCESS}

${ }^{1}$ Thoracic Surgery, Valais Hospital, Sion, Switzerland ${ }^{2}$ Thoracic Surgery, Lausanne University Hospital, Lausanne, Switzerland

${ }^{3}$ Pathology, Valais Hospital, Sion, Switzerland

Correspondence to Dr Céline Forster, Thoracic Surgery, Valais Hospital, Sion 1951, Switzerland; celine.forster@hopitalvs.ch

Received 9 February 2021 Accepted 31 May 2021 Published Online First 24 June 2021

\title{
Evolutive diaphragmatic lesions causing recurrent catamenial pneumothorax
}

\author{
Céline Forster, ${ }^{1,2}$ Charles Bénière, ${ }^{3}$ Justine Lattion, ${ }^{1}$ Jean Yannis Perentes, ${ }^{1,2}$ \\ Michel Christodoulou ${ }^{1}$
}

A 47-year-old woman was diagnosed with pelvic endometriosis during a caesarean at the age of 37 years. Two years later, she presented two episodes of spontaneous right-sided pneumothorax occurring 2 days after the onset of her menses. The first episode was treated with pleural drainage and the chest CT scan did not show parenchymal or diaphragmatic anomalies. A second episode occurred 1 month later and the patient underwent thoracoscopic exploration, wedge resection of the lung apex and mechanical pleurodesis. During this intervention, multiple dark elliptical nodules were identified on the tendinous part of the diaphragm (figure 1A) and biopsies confirmed the presence of endometriosis (figure 1B,C). Since then, a progestin therapy (dienogest) was introduced at a daily dosage of $2 \mathrm{mg}$. Eight years later, the patient presented a third episode of right-sided pneumothorax. A thoracoscopic re-exploration was performed and multiple small elliptical perforations were identified on the tendinous part of the diaphragm, at the same location where endometriosis nodules had initially been observed (figure 2). A talc pleurodesis was performed and since then, the patient did not present any recurrence with an ongoing daily treatment of $2 \mathrm{mg}$ dienogest.

Thoracic endometriosis can cause recurrent, preferentially right-sided catamenial pneumothorax,

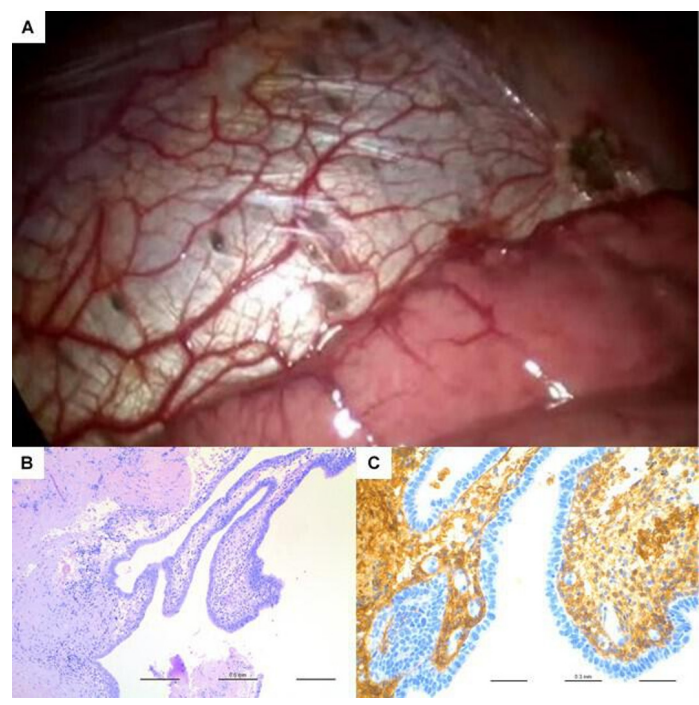

Figure 1 (A) Multiple dark epiphrenic nodules found during thoracoscopic exploration for catamenial pneumothorax. (B) Histological assessment of a biopsied nodule revealing typical endometrial gland tissue with fibrous reaction $(\mathrm{H} \& \mathrm{E} \times 100)$ with $(\mathrm{C})$ positive immunohistochemical staining for CD10 within the stroma $(\times 200)$.

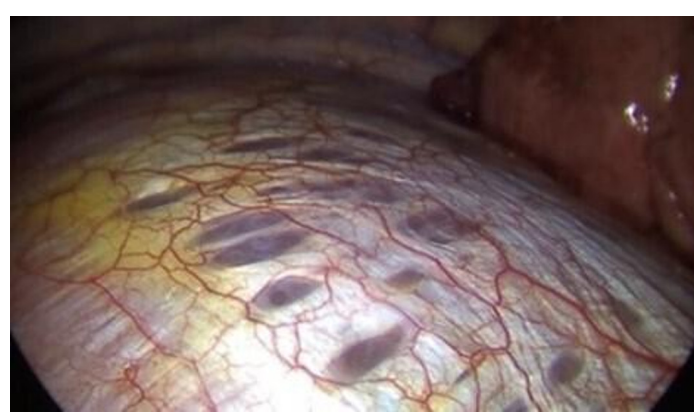

Figure 2 Thoracoscopic evaluation in the same patient on the same side performed 8years after the first intervention for recurrent catamenial pneumothorax revealing multiple small elliptic diaphragmatic perforations at the site of the initially localised epiphrenic endometrial nodules.

which is often associated with multiple small diaphragmatic defects situated in the tendinous part of the diaphragm as well as endometrial implants within the chest cavity. ${ }^{12}$ This report clearly demonstrates (and to our knowledge for the first time) that epiphrenic endometrial implants have erosive properties with subsequent development of diaphragmatic defects causing recurrent pneumothorax. These findings have to be taken into consideration for the management of this relatively rare entity, which is ideally approached in an interdisciplinary setting.

Contributors $C F, J L, J Y P$ and $M C$ contributed to the planning and writing of the article. CB provided figures. All authors reviewed the article.

Funding The authors have not declared a specific grant for this research from any funding agency in the public, commercial or not-for-profit sectors.

Competing interests None declared.

Patient consent for publication Not required.

Provenance and peer review Not commissioned; externally peer reviewed.

Open access This is an open access article distributed in accordance with the Creative Commons Attribution Non Commercial (CC BY-NC 4.0) license, which permits others to distribute, remix, adapt, build upon this work non-commercially, and license their derivative works on different terms, provided the original work is properly cited, appropriate credit is given, any changes made indicated, and the use is non-commercial. See: http:// creativecommons.org/licenses/by-nc/4.0/.

\section{REFERENCES}

1 Korom S, Canyurt H, Missbach A, et al. Catamenial pneumothorax revisited: clinical approach and systematic review of the literature. $J$ Thorac Cardiovasc Surg 2004;128:502-8.

2 Visouli AN, Zarogoulidis K, Kougioumtzi I, et al. Catamenial pneumothorax. J Thorac Dis 2014;6:S448-60. 